\title{
Sisteme inteligente de măsurare a comportamentului conducătorului autovehiculului pe parcursul traseului ales de instructor
}

\author{
Mihaela Popa Chraif ${ }^{1}$ \\ Universitatea din Bucureşti \\ Eusebiu Catana \\ ITS\&Telematics Consultants, Brussels, Belgium
}

Sistemul LG-DS (Ladies\&Gentlemen Drivers System), un produs informatizat de urmărire a comportamentului conducătorului auto (apărut în mai-iunie 2005) are mare succes în SUA, Franța, Belgia şi Suedia. În SUA a fost implementat ca program național în toate şcolile de şoferi. Acolo şcoala de şoferi se face începând de la 16 ani. Pregătirea/testatrea/evaluarea practică pe traseu se face prin intermediul sistemului LGDS.

LG-DS include: senzorii aferenți, 2 camere video, un laptop de ultimă generație cu sistem touch screen, interfață video, soft-ul instalat şi licența de folosire, suport camere video, toate acestea puse într-o geantă metalică din aluminiu pentru a putea $\mathrm{fi}$ transportată şi instalată la locul utilizării.

Echipamentul LG-DS are utilizare bivalentă şi se foloseste la pregătirea şi verificarea obiectivă a experienței practice acumulate de către şoferi.

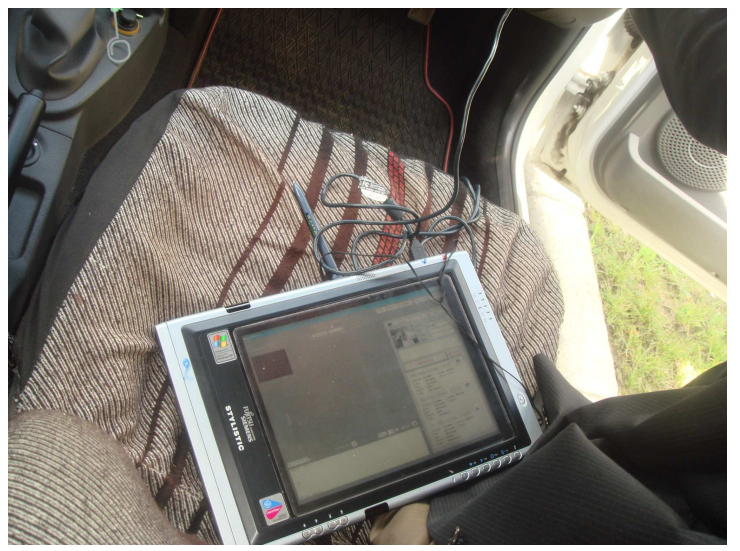

Figura 1. Sistem touch screen, interfață video

Din punctul de vedere al pregătirii, sistemul LG-DS se foloseşte la formarea şi

\footnotetext{
${ }^{1}$ Adresa de corespondență: mihaelapopa14@yahoo.com
}

perfecționarea deprinderilor viitorului şofer. De exemplu, dacă şcoala de şoferi durează 4 săptămâni, se recomandă ca să fie folosit în timpul procesului de pregătire practică o data în primele 3 săptamâni (ca să se vadă cum progresesează viitorul şofer) şi la toate şedințele practice de conducere din ultima săptămână. Mai mult decât atât, sistemul se poate utiliza şi la şedințele teoretice de însuşire a cunoştințelor necesare traficului rutier.

Având în vedere verificarea obiectivă a experienței practice acumulate de către şoferi, este bine de ştiut că sistemul reprezintă la ora actuală singura modalitate obiectivă de verificare practică pe traseu a viitorului şofer. Aşa cum reiese din experiența acumulată cu şcolile de şoferi din Belgia, un astfel de sistem este recomandat atât şcolilor de şoferi cât şi poliției rutiere care face verificarea pe traseu.

Acest sistem elimină subiectivitatea la evaluarea performațelor în conducere dar şi în aprecierea conduitei expresiv-emotionale a şoferului în timpul conducerii autovehiculului.

Sistemul se poate folosi cu mici adaptări la automobile, camioane, autobuze, tir-uri, troleibuze până la tramvaie.

\section{Modul de utilizare al sistemului LG-DS (Ladies\&Gentlemen Drivers System)}

Sistemul descris, înregistrează în memoria laptop-ului comportamentul participantului la operațiunea de conducere a autovehiculului. Instructorul are posibilitatea să vadă în orice moment unde a greşit potențialul şofer. Astfel, instructorul îi poate da explicațiile necesare minimizării numărului de erori în conducere. Alte explicații se mai pot da şi la şedințele teoretice de pregătire când, prin analize de caz se poate analiza detaliat cum a condus potențialul şofer pe traseul ales. 
Sistemul LG-DS înregistrează comportamentul şi conduita expresivemoțională a conducătorului autovehiculului pe traseu urmărind două axe: longitudinală şi laterală (Figura 2).
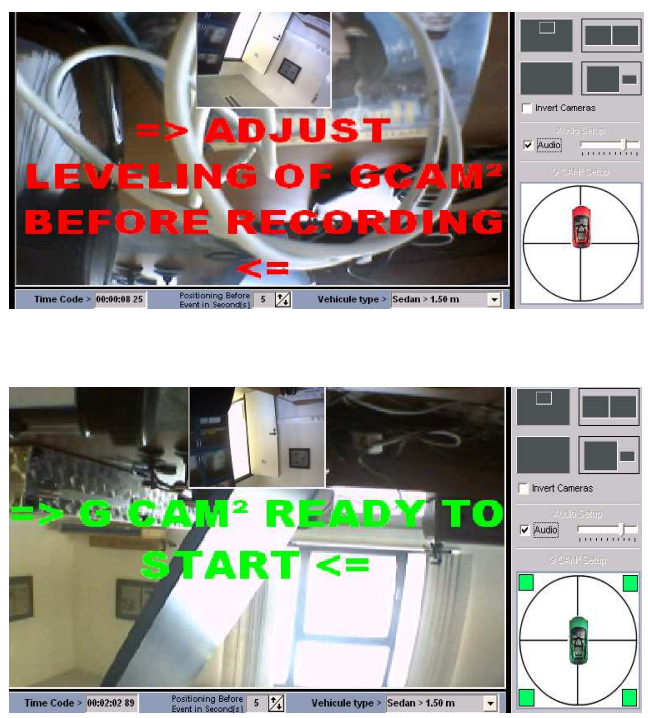

Figura 2. Ajustarea urmărind cele două axe: longitudinală şi laterală

Din punctul de vedere al analizei comportamentului conducătorului autovehiculului se poate vedea atât în timpul executării traseului ce anume şi cum a greşit şoferul, dar şi în timpul staționării, când se poate lua o scurtă pauză pe traseu unde se poate discuta cu conducătorul autovehiculului unde a greşit şi cum să actioneze corect (Figura 3).

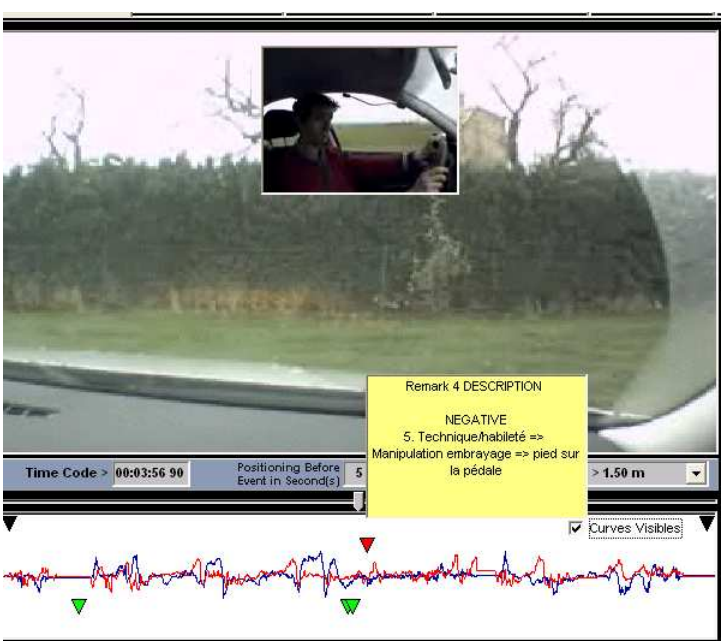

Figura 3. Imagini înregistrate pe traseu cu analiza erorilor

Rezultatele se pot înregistra într-o bază de date (Figura 4), structurată în fişiere separate pentru fiecare şofer şi se poate compara evoluția modului de conducere a autovehiculului de la intrarea în şcoală şi până la terminarea ei. Instructorul poate garanta sau nu dacă acel potențial şofer are aptitudini şi deprinderi formate de conducere a autovehiculului, dacă poate să ia permis de conducere şi dacă va conduce cu siguranță în trafic. Toate datele înregistrate cu ajutorul camerelor video şi a sezorilor de voce sunt procesate automat de programul soft al sistemului LG-DS. Este important de menționat că instructorul nu poate interveni să influențeze "rezultatele" colectate de pe traseul parcurs ale conducătorului autovehiculului.

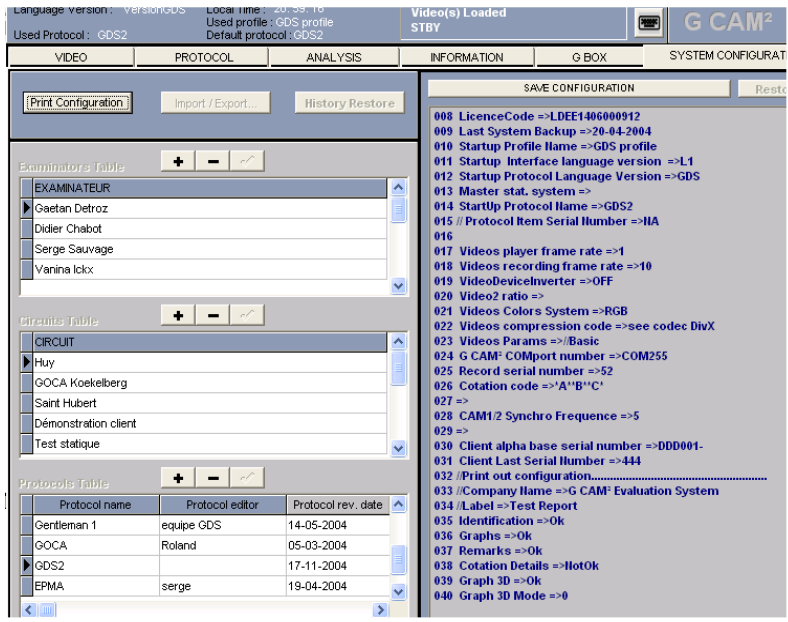

Figura 4. Baza de date stocată a şoferilor testați pe traseu

Cantitatea de informatie stocată depinde de cât este mărimea hard-discului. Practic dacă pentru un cursant este necesar $1 \mathrm{MB}$ şi hard-discul are $20 \mathrm{~GB}$, în practică s-ar putea stoca date pentru 20000 cursanți fără să se mai şteargă nimic din sistem. Dar, dacă am avea un hard-disck mai mare şi unul extern, practic se pot stoca informații pentru un an, fără a se apela la suport de memorie externă.

Datele înregistrate pe parcursul traseului de către conducătorii autovehiculului ar putea fi folosite şi din punct de vedere legal, să se demonstreze că un individ care a luat la un anumit moment examenul pentru carnet de conducere avea un comportament corespunzător la volan şi o conduită expresivemoțională cât mai aproape de cea ideală.

Datorită faptului că sistemul înregistrează totul în fişiere pentru fiecare cursant în parte, se poate tipări o fişă la fiecare şedință de pregătire, unde i se pot arăta 
greşelile făcute pe traseu şi i se va explica ce trebuie să facă pentru a minimiza numărul acestora. După examinare, fişa se poate ataşa dosarului cursantului împreună cu rezultatele de la chestionarele teoretice.

Pregătirea şi examinarea poate avea mai multe sau mai puține etape. Este la latitudinea instructorului să aleagă aceste etape în funcție de cât de repede conducătorul autovehiculului adoptă un comportament cât mai lipsit de erori în timpul conducerii autovehiculului.

În timpul conducerii autovehiculului, orice mişcare a autovehicului este monitorizată, înregistrată şi prelucrată de softul sistemului. Orice eroare efectuată de către conducătorul autovehiculului este afişată în timp real pe ecran şi înregistrată sub formă de fişier în memoria calculatorului.

Aşa cum am prezentat anterior, rezultatele evaluării cursantului se pot prezenta fie după fiecare manevră, fie în timpul şedintei sau chiar la finalul şedinței de conducerea a autovehiculului.

Sistemul LG-DS oferă toate informațiile de care instructorul are nevoie pentru a analiza conduita expresiv emoțională, comportametul la volan şi numărul erorilor realizate de către persoana care conduce pe traseul ales. De asemenea, se poate vizualiza o listă cu obiectivele urmărite şi o înregistrare video a comportamentului conducătorului autovehiculului pe întregul traseu ales.

Informațiile oferite de către sistemul LG-DS se referă nu numai la acțiunea conducătorului autovehiculului în mod direct, dar şi indirect. Astfel că după o corectare a unei greşeli se poate verifica dacă acesta a fost îndrumat corect de către instructor pentru a efectua corect manevra respectivă.

Pregatirea instructorului (şi a examinatorului): la început se face de către o persoană autorizată care a efectuat un anumit număr de ore de pregătire în utilizarea şi interpretarea rezultatelor testării. Se impune o astfel de procedură foarte strictă, pentru că trebuie să respectăm normele ISO9001 în domeniul respectiv.

Ciclul pentru obținerea atestatului de utilizare a sistemului ar fi următorul:

- $\quad$ pregătire teoretică generală;

- detalii despre sistem, mod de funcționare, mod de utilizare, mod de folosire a datelor, de citire şi interpretare a erorilor, mod de corectare a erorilor;

- o şedință demonstrativă;
- $\quad$ trei şedințe practice de învătare cu fiecare instructor în parte, urmate de prelucrarea datelor înregistrate sub supraveghere;

- 1-2 şedințe practice în care instructorii interpretează singuri datele înregistratge;

- Examen teoretic şi examen practic.

Service-ul acordat sistemului LC-DS nu este necesar deoarece totul este încapsulat în softul utilizat. Dar dacă apar disfuncții, producătorul oferă orice tip de service necesar.

Este foarte puțin probabil să apară ceva neprevăzut în timpul examinării la sistem. În cazul în care apare o disfuncție, cum ar fi întreruperea fluxului informațional de la senzori, sau imposibilitatea recepționării de imagini video, se verifică încă o dată instalarea corectă a sistemului.

Practic, în toate țările unde s-a prezentat sistemul a avut şi are în continuare un succes deosebit. În plus, ceea ce este şi mai interesant, în Belgia toți şoferii care sunt prinşi cu limita alcoolemiei în sânge depăşită sau că au consumat droguri la volan, li se ridică permisul şi nu li se mai înnapoiază până când nu fac şcoala de şoferi asistată de sistemul LG-DS şi trec examenul. Sistemul permite ca acea fişă de evaluare să fie integrată în sistemul electronic şi sa fie înregistrată împreună cu toate rezultatele cursantului. 